dr hab. Paweł Ulman

Uniwersytet Papieski

Jana Pawła II w Krakowie
Eliminacja wykluczenia społecznego, red. M. Duda, K. Kutek-Sładek, Kraków 2017, s. 145-159 (Praca Socjalna w Teorii i Działaniu, 3).

DOI: http://dx.doi.org/10.15633/9788374385824.10

\title{
Źródła zaspokojenia bieżących potrzeb gospodarstw domowych o niskich dochodach
}

\author{
Sources to meet the current needs of households \\ with low incomes
}

\begin{abstract}
The problem of low income households in Poland is quite common. As it was shown by Polish CSO extreme poverty (subsistence minimum) affects more than 7 percent of people in Poland, and at the level of the statutory criterion of poverty, nearly 13 percent (average data from the 2013). The interesting research problem is to identify the sources of widely understood income (cash and in kind) and their importance to meet the current needs of households with low incomes in connection with a wide range of extreme poverty arising from low
\end{abstract}

income of households. The aim of the work is to present the results of statistical analysis of the level of income from various sources affecting the ability to satisfy the current needs of the poor households. So it is going to be shown how these households cope with basic needs. The statistical analysis are made on the basis of data published by the CSO and the data from the study "Social Diagnosis".

Keywords: poverty, low incomes, households, needs

Minęło 25 lat transformacji społeczno-gospodarczej w Polsce. Niewątpliwie w wielu obszarach życia społecznego nastąpiła znacząca poprawa. Jeździmy po lepszych drogach, organizujemy imprezy sportowe na światowym poziomie, mamy możliwość zakupu dowolnego towaru lub usługi, możemy kształcić się na każdym 
poziomie prawie bez ograniczeń, mamy wolność słowa i wyznania. Jednak są takie grupy społeczne, które w niewielkim stopniu zyskały na przemianach. Nie jeżdżą po tych lepszych drogach, bo nie stać ich na samochód lub paliwo do niego, lub wreszcie na opłaty za przejazd najdroższymi w Europie autostradami. Z braku środków finansowych nie oglądają na żywo owych imprez sportowych. Z tych samych względów ich wolność wyboru towarów i usług jest ograniczona do najtańszych produktów. Często nie korzystają oni z możliwości teoretycznie bezpłatnego kształcenia, a ich wolność słowa jest także ograniczana tym, że niewielu jest takich, którzy chcieliby ich słuchać. Z tego braku słuchania przez tych, którzy mają możliwości wprowadzenia realnych zmian w życiu najuboższych, wynika fakt, że problem ubóstwa w Polsce od dłuższego czasu z pewnością nie zanika, jeśli nie narasta.

W swoim nauczaniu społecznym Kościół katolicki zwraca uwagę na problem ubóstwa i biedy, formułując potrzebę wprowadzenia do życia społecznego zasad sprawiedliwości i równości społecznej w stosunkach międzyludzkich. Tymczasem owej sprawiedliwości brakuje na poziomie zarówno międzypaństwowym, jak i poszczególnych społeczeństw. Przywołując encyklikę ojca świętego Jana Pawła II Solicitudo rei socialis, papież wielokrotnie wskazywał na konieczność zaistnienia sprawiedliwości w życiu społecznym, mówiąc m.in. o sprawiedliwym uczestnictwie w dobrach i usługach przeznaczonych dla wszystkich ${ }^{1}$, równym podziale owoców prawdziwego rozwoju, wynikającym ze sprawiedliwości ${ }^{2}$ oraz sprawiedliwości w stosunkach pracy ${ }^{3}$. Ponadto papież wspomina, że sprawiedliwość społeczna i międzynarodowa jest drogą do osiągnięcia upragnionego pokoju ${ }^{4}$. Zbytnia nierówność podziału dóbr, w tym dochodów i wynagrodzeń, wynika najczęściej z zaistnienia niesprawiedliwości, co urzeczywistnia się w tym, że jedni (raczej nieliczni) uzyskują wysoki poziom bogactwa, podczas gdy inni (często liczniejsi) nie mają możliwości zaspokojenia nawet podstawowych potrzeb. Taką sytuację przedstawiał Jan Paweł II w encyklice Centesimus annus ${ }^{5}$, przywołując słowa papieża Leona XIII z encykliki Rerum novarum. Minęło więc ponad sto lat dynamicznego rozwoju społeczno-ekonomicznego, a wciąż spotykamy się ze wspomnianą wyżej niesprawiedliwością zbyt nierównego podziału dóbr i korzyści w skali międzynarodowej i poszczególnych społeczeństw. Cały czas duża część ludzkości doświadcza skrajnego ubóstwa, a owo doświadczanie nie jest rzadkie również w państwach o wysokim poziomie rozwoju. Jak wiadomo ubóstwo - rozumiane szeroko (ubóstwo materialne i duchowe), jak i wąsko

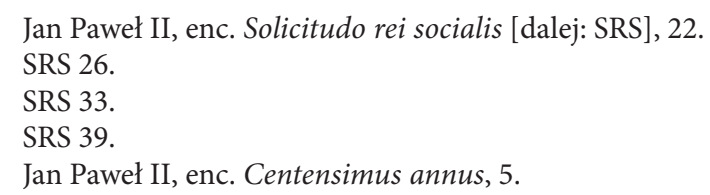


jako brak środków ekonomicznych niezbędnych do zaspokojenia określonych potrzeb - jest problemem indywidualnym i społecznym. Jako problem społeczny wymaga on zainteresowania i interwencji instytucji państwowych w celu ograniczenia jego dotkliwości lub całkowitej likwidacji. W tym kontekście nasuwa się pytanie o skuteczność polskiej polityki społecznej w zakresie ubóstwa. Jak już wyżej wspomniano, w ciągu 25 lat transformacji systemowej nie rozwiązano w Polsce kwestii ubóstwa, co więcej dane statystyczne nie wskazują nawet na jego istotne zmniejszanie się. Patrząc więc na „owoce” polskiej transformacji w tym jednym, ale ważnym obszarze - zaspokojenia odpowiednich potrzeb na takim poziomie, by każdy człowiek i każda rodzina mogli godnie żyć i funkcjonować w społeczeństwie - można z żalem i niepokojem stwierdzić, że w znacznym zakresie nie rozwiązaliśmy jako społeczeństwo kwestii ubóstwa. Ciągle zbyt wiele jest w Polsce osób, które żyją w warunkach nieustannych niedoborów środków finansowych, co przekłada się na niezaspakajanie nawet podstawowych potrzeb.

Celem niniejszej pracy jest przedstawienie wyników statystycznej analizy poziomu dochodów z różnych źródeł, mających wpływ na możliwości zaspokojenia bieżących potrzeb biednych gospodarstw domowych. Zostanie więc zaprezentowane, jak te gospodarstwa domowe radzą sobie z zaspokajaniem wspomnianych potrzeb w zależności od sytuacji ekonomicznej. Sygnalizowana analiza statystyczna zostanie dokonana na podstawie danych publikowanych przez GUS oraz danych z badania „Diagnoza społeczna”.

\section{Ubóstwo w Polsce}

Badanie ubóstwa w zakresie jego skali i intensywności jest trudnym zadaniem. Trudność ta wynika z braku jednoznacznej definicji tego zjawiska, co jednak należy uznać za immamentną cechę zjawisk społecznych. Nie należy się bowiem spodziewać, że w ten sam sposób będziemy jako społeczeństwo postrzegać problem ubóstwa, w ten sam sposób je rozumieć i w konsekwencji w ten sam sposób je mierzyć. Mimo tych przeszkód podaje się definicję ubóstwa jako niezaspokojenie potrzeb na pożąanym poziomie ${ }^{6}$. Na bazie tej ogólnej definicji opracowuje się sposoby identyfikacji jednostek (osób, rodzin, gospodarstw domowych), które można lub należy uznać za ubogie ${ }^{7}$. W publikacjach GUS wykorzystuje

6 Por. T. Panek, Ubóstwo, wykluczenie społeczne i nierówności. Teoria i praktyka pomiaru,Warszawa 2011, s. 12.

7 Więcej na ten temat można znaleźć w: I. Topińska, Kierunki zmian w statystyce ubóstwa, [w:] Pomiar ubóstwa. Zmiany koncepcji i ich znaczenie, pod red. I. Topińskiej, Warszawa 2008 , s. 17-26. 
trzy koncepcyjnie różne granice ubóstwa (linie ubóstwa). Pierwsza z nich jest określana jako ustawowa granica ubóstwa, a jej poziom jest tożsamy z kryterium dochodowym pozwalającym na ubieganie się o zasiłek z pomocy społecznej. Druga linia ubóstwa - minimum egzystencji - należy do kategorii tzw. absolutnych granic ubóstwa. Wyznaczana jest ona przez zespół ekspertów Instytutu Pracy i Spraw Socjalnych na podstawie określenia koszyka dóbr, niezbędnych do podtrzymania funkcji życiowych człowieka i sprawności psychofizycznej. Koszyk ten jest później wyceniany, co w konsekwencji przekłada się na dochód niezbędny do zaspokojenia wskazanych potrzeb na określonym poziomie ${ }^{8}$. Trzecia linia ubóstwa należy do tzw. relatywnych granic ubóstwa. To podejście preferowane jest przez Eurostat i polega na wyznaczeniu kryterium dochodowego jako 60 proc. mediany dochodów ekwiwalentnych. W tym przypadku problematyczne jest również wykorzystanie odpowiedniej skali ekwiwalentności.

Na wykresie 1 zaprezentowano kształtowanie się stopy ubóstwa w Polsce w okresie od 2004 do 2014 roku, której wartości określono przy założeniu trzech wspomnianych wyżej granic ubóstwa obliczanych dla każdego roku. Po wstąpieniu Polski do UE zasięg skrajnego ubóstwa początkowo znacznie się obniżył, po czym od 2008 roku powoli, ale sukcesywnie wzrastał. Z kolei zasięg ubóstwa relatywnego systematycznie spadał w badanym okresie, jednak skala tego spadku jest raczej niewielka.

W przypadku ubóstwa ustawowego brak rewaloryzacji granicznego poziomu dochodów dla uzyskania zasiłków z pomocy społecznej spowodował wyraźne obniżenie się zasięgu ubóstwa. Podniesienie poziomu wspomnianego dochodu w 2013 roku skutkowało zasadniczym wzrostem skali zubożenia z poziomu 7,2 proc. w roku 2012 do ponad 12 proc. w kolejnych latach.

Utrzymujące się znaczne zubożenie polskiego społeczeństwa współistnieje z dynamicznym wzrostem przeciętnych dochodów i wydatków na osobę gospodarstw domowych. W badanym okresie 10 lat przeciętne nominalne dochody wzrosły o $579 \mathrm{zł} \mathrm{z} \mathrm{poziomu} 761 \mathrm{zł} \mathrm{w} 2005$ roku do poziomu $1340 \mathrm{zł} \mathrm{w} \mathrm{roku} 2014^{9}$. Przyrost wydatków był mniej dynamiczny i wynosił 389 zł. To zróżnicowanie dynamiki dochodów i wydatków spowodowało znaczący spadek udziału wydatków w dochodach z poziomu 90,7 do 80,5 proc., co skutkuje wzrostem oszczędności gospodarstw domowych. Brak istotnego przełożenia wzrostu dochodów gospo-

8 Więcej na ten temat można znaleźć na stronach internetowych IPiSS lub w: P. Kurowski, Koszyk minimum socjalnego i minimum egzystencji - dotychczasowe podejście, Warszawa 2002 (artykuł można znaleźć pod adresem https://www.ipiss.com.pl/?zakla$\mathrm{dy}=$ minimum-socjalne-oraz-minimum-egzystencji (dostęp: 15.11.2015).

9 Dane na temat dochodów i wydatków gospodarstw domowych zaczerpnięto z GUS, Budżety gospodarstw domowych w 2014 r. Informacje i opracowania statystyczne, Warszawa 2015, s. 41-49. 
darstw domowych na kształtowanie się (zmniejszanie) zakresu ubóstwa nasuwa wniosek zarysowany we wstępie, że istniej w Polsce duża grupa społeczeństwa, która nie doświadcza korzyści płynących z rozwoju społeczno-gospodarczego. Biorąc pod uwagę gospodarstwa o najniższych dochodach (pierwsza grupa kwintylowa), w 2014 roku udział wydatków w dochodach wynosił blisko 128 proc. (wydatki były większe niż dochody), co nasuwa podejrzenia o finansowanie potrzeb tych gospodarstw domowych $\mathrm{z}$ niezarejestrowanych $\mathrm{w}$ ramach badania budżetów gospodarstw domowych źródeł. Trudno bowiem przyjąć, że gospodarstwa domowe o niskich dochodach uzupełniają braki środków finansowych jedynie z oszczędności z okresów wcześniejszych.

Wykres 1. Zasięg ubóstwa w Polsce w latach 2005-2014

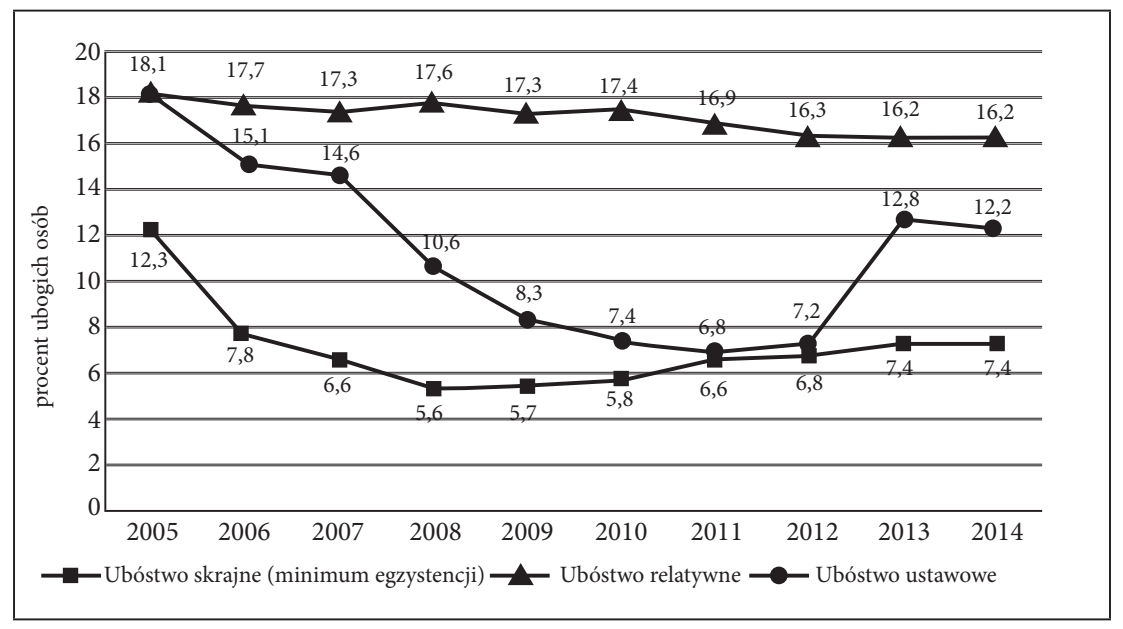

Źródło: GUS, Ubóstwo ekonomiczne w Polsce w 2014 r., Opracowanie sygnalne, http://stat. gov.pl/obszary-tematyczne/warunki-zycia/ubostwo-opieka-spoleczna/ubostwo-ekonomiczne-w-polsce-w-2014-r-,14,2.html (dostęp: 15.11.2015).

Wspomniane wyżej w sposób ogólny dochody są mierzone przez GUS w ramach kategorii dochodów rozporządzalnych, które w uproszczony sposób można zdefiniować jako sumę bieżących dochodów gospodarstwa domowego z poszczególnych źródeł, pomniejszoną o podatek dochodowy oraz składki na ubezpieczenie społeczne i zdrowotne ${ }^{10}$. Wspomniane źródła dochodów

10 Szczegółową definicję dochodu rozporządzalnego można znaleźć w: GUS, Metodologia badania budżetów gospodarstw domowych, Warszawa 2011, s. 33. 
przedstawiają się następująco. Dochody mogą pochodzić z: pracy najemnej, gospodarstwa indywidualnego $\mathrm{w}$ rolnictwie, pracy na własny rachunek lub wykonywania wolnego zawodu, tytułu własności, wynajmu nieruchomości, świadczeń z ubezpieczeń społecznych, pozostałych świadczeń oraz innych źródeł. W tabeli 1 pokazano przeciętne wartości miesięcznych dochodów na osobę ze względu na źródło tego dochodu i dochodową grupę kwintylową.

Tabela 1. Kwintyle i średnie miesięcznego dochodu rozporządzalnego na osobę z poszczególnych źródeł w układzie grup kwintylowych, 2014.

\begin{tabular}{|c|c|c|c|c|c|c|}
\hline \multirow{2}{*}{ Wyszczególnienie } & \multirow{3}{*}{ Ogółem } & \multicolumn{5}{|c|}{ grupa kwintylowa } \\
\hline & & 1 & 2 & 3 & 4 & 5 \\
\hline kwintyl & & 693,84 & 1010,18 & 1363,33 & 1866,67 & $\mathrm{x}$ \\
\hline dochód ogółem & 1340,44 & 429,74 & 832,07 & 1149,28 & 1548,06 & 2748,25 \\
\hline z pracy najemnej & 732,57 & 234,62 & 469,35 & 630,96 & 787,47 & 1498,36 \\
\hline $\begin{array}{l}\text { z pracy na własny ra- } \\
\text { chunek }\end{array}$ & 114,51 & 23,95 & 53,85 & 73,41 & 111,64 & 310,46 \\
\hline dochód $\mathrm{z}$ rolnictwa & 44,65 & $-35,91^{\star}$ & 24,16 & 36,5 & 42,35 & 156,59 \\
\hline $\begin{array}{l}\text { ze świadczeń z ubezpie- } \\
\text { czeń społecznych }\end{array}$ & 343,09 & 94,22 & 186,33 & 319,02 & 508,91 & 607,84 \\
\hline emerytury krajowe & 270,15 & 53,39 & 120,75 & 241,44 & 421,28 & 514,7 \\
\hline $\begin{array}{l}\text { renty z tytułu niezdol- } \\
\text { ności do pracy }\end{array}$ & 32,11 & 24,66 & 37,44 & 39,29 & 35,9 & 23,23 \\
\hline renty rodzinne krajowe & 31,26 & 11,41 & 20,1 & 29,78 & 42,76 & 52,32 \\
\hline $\begin{array}{l}\text { z pozostałych świadczeń } \\
\text { społecznych }\end{array}$ & 44,61 & 83,35 & 57,65 & 37,15 & 22,83 & 22,01 \\
\hline $\begin{array}{l}\text { zasiłki dla bezrobotnych } \\
\text { krajowe }\end{array}$ & 3,46 & 5,29 & 4,71 & 3,91 & 2,25 & 1,12 \\
\hline pozostałe dochody & 65,03 & 29,04 & 39,96 & 50,9 & 71,79 & 133,73 \\
\hline dary & 60,02 & 27,91 & 38,24 & 48,44 & 67,08 & 118,67 \\
\hline
\end{tabular}

* W przypadku dochodów z działalności rolniczej możliwe są ujemne dochody jako wynik różnicy przychodów i kosztów tej działalności.

Źródło: opracowanie własne na podstawie GUS, Budżety gospodarstw domowych w $2014 r$. Informacje i opracowania statystyczne, Warszawa 2015, tab. 19. 
Oczywiste jest, że wraz ze wzrostem zamożności gospodarstwa domowego rośnie przeciętny dochód na osobę, jednak ważną obserwacją jest skala przyrostu dochodu w układzie grup kwintylowych. Przeciętne dochody ogółem w piątej grupie kwintylowej są ponad sześć razy wyższe niż w pierwszej. Ogólnie wzrost zamożności gospodarstwa domowego wiąże się z przyrostem dochodu w przypadku prawie każdego źródła dochodu. Jedynie dochody z pozostałych świadczeń społecznych prezentują odmienny kierunek zmian ich poziomu. W celu przekonania się o znaczeniu danego źródła dochodów dla gospodarstw domowych w tabeli 2 zaprezentowano udziały tych dochodów w dochodach ogółem. Z badania wspomnianej struktury wyłączono dochody z rolnictwa, których wartości mogą być ujemne.

Większość dochodów polskich gospodarstw domowych pochodzi z pracy najemnej, a później z ubezpieczeń społecznych. W przypadku najbiedniejszych gospodarstw duże znaczenie jako źródło dochodów mają pozostałe świadczenia społeczne, zwłaszcza w porównaniu z gospodarstwami o wyższych dochodach ogółem. Natomiast mniejszy wkład mają przede wszystkim dochody z pracy na własny rachunek i emerytury krajowe. Obecnie w Polsce przeciętnie emerytury pozwalają uzyskiwać relatywnie wysokie dochody na osobę, co powoduje, że stanowią one często źródło dochodów lepiej sytuowanych gospodarstw.

Tabela 2. Struktura źródeł dochodu rozporządzalnego polskich gospodarstw domowych w układzie grup kwintylowych (w \%)

\begin{tabular}{|c|c|c|c|c|c|c|}
\hline \multirow{2}{*}{ Dochód } & \multirow{2}{*}{ Ogółem } & \multicolumn{5}{|c|}{ Grupa kwintylowa } \\
\hline & & 1 & 2 & 3 & 4 & 5 \\
\hline z pracy najemnej & 56,36 & 50,44 & 58,15 & 56,77 & 52,41 & 58,25 \\
\hline $\begin{array}{l}\text { z pracy na własny ra- } \\
\text { chunek }\end{array}$ & 8,81 & 5,15 & 6,67 & 6,60 & 7,43 & 12,07 \\
\hline $\begin{array}{l}\text { ze świadczeń z ubezpie- } \\
\text { czeń społecznych }\end{array}$ & 26,40 & 20,25 & 23,09 & 28,70 & 33,87 & 23,63 \\
\hline emerytury krajowe & 20,78 & 11,48 & 14,96 & 21,72 & 28,04 & 20,01 \\
\hline $\begin{array}{l}\text { renty } \mathrm{z} \text { tytułu niezdol- } \\
\text { ności do pracy }\end{array}$ & 2,47 & 5,30 & 4,64 & 3,54 & 2,39 & 0,90 \\
\hline renty rodzinne krajowe & 2,40 & 2,45 & 2,49 & 2,68 & 2,85 & 2,03 \\
\hline $\begin{array}{l}\text { z pozostałych świad- } \\
\text { czeń społecznych }\end{array}$ & 3,43 & 17,92 & 7,14 & 3,34 & 1,52 & 0,86 \\
\hline
\end{tabular}




\begin{tabular}{|l|c|c|c|c|c|c|}
\hline \multirow{2}{*}{\multicolumn{1}{c|}{ Dochód }} & \multirow{2}{*}{ Ogółem } & \multicolumn{5}{|c|}{ Grupa kwintylowa } \\
\cline { 3 - 7 } & & 1 & 2 & 3 & 4 & 5 \\
\hline $\begin{array}{l}\text { zasiłki dla bezrobot- } \\
\text { nych krajowe }\end{array}$ & 0,27 & 1,14 & 0,58 & 0,35 & 0,15 & 0,04 \\
\hline pozostałe dochody & 5,00 & 6,24 & 4,95 & 4,58 & 4,78 & 5,20 \\
\hline dary & 4,62 & 6,00 & 4,74 & 4,36 & 4,46 & 4,61 \\
\hline
\end{tabular}

Źródło: opracowanie własne na podstawie GUS, Budżety gospodarstw domowych w 2014 r. Informacje i opracowania statystyczne, Warszawa 2015, tab. 19.

\section{Bieżące potrzeby gospodarstw domowych i ich zaspokajanie}

Powyższe dane - zaczerpnięte z GUS-u - pokazały, że istnieje zróżnicowanie źródeł dochodów gospodarstw domowych w zależności od ich poziomu. W dalszej części pracy przy wykorzystaniu danych z badania „Diagnoza społeczna” z 2013 roku $^{11}$ analizie zostaną poddane przede wszystkim poziom zaspokojenia bieżących potrzeb gospodarstw domowych i źródła ich zaspokojenia w przypadku gospodarstw z niewystarczającymi dochodami.

W ramach wspomnianego badania zadaje się respondentom pytanie o możliwość „wiązania końca z końcem” w bieżącej sytuacji dochodowej. Okazuje się, że 17 proc. gospodarstw przyznało, że czyni to z wielką trudnością, 19 proc. z trudnością, a 35 proc. z pewną trudnością. Wynika z tego, że jedynie 29 proc. gospodarstw domowych nie odczuwa trudności w gospodarowaniu swoim budżetem, a blisko jedna piąta ma z tym wielkie trudności. W kolejnym kroku zapytano respondentów, jaki poziom dochodu pozwoliłby im „wiązać koniec z końcem", co pozwala na obliczenie różnicy dla każdego badanego gospodarstwa między dochodem rzeczywistym a dochodem postulowanym jako ten minimalny. Podstawowe charakterystyki rozkładu owej różnicy w układzie możliwości „wiązania końca z końcem” przedstawia tabela 3.

11 Więcej na temat badania Diagnoza społeczna można znaleźć w: Diagnoza społeczna 2013. Warunki i jakość życia Polaków. Raport,. pod red. J. Czapińskiego, T. Panka, www. diagnoza.com (dostęp: 15.11.2015). 
W gospodarstwach domowych, które deklarują trudną sytuację dochodową, średnia różnica wspomnianych dochodów przyjmuje wartości ujemne, co wskazuje na przeciętny niedobór rzeczywistych dochodów w odniesieniu do dochodów postulowanych jako minimalne. W przypadku gospodarstw deklarujących wielkie trudności w „wiązaniu końca z końcem” połowa z nich doświadcza niedoboru dochodu na poziomie co najmniej 400 zł, a 75 proc. ma dochody rzeczywiste nie większe niż te postulowane. Gospodarstwa o najlepszej sytuacji dochodowej cieszą się znaczną nadwyżką dochodu rzeczywistego nad tym minimalnym. Pierwsze 25 proc. gospodarstw (co do poziomu dochodu) ma ową nadwyżkę nie większą niż 975 zł a ostatnie 25 proc. dysponuje dochodami wyższymi od dochodu minimalnego o co najmniej 3500 zł. Ogólnie połowa gospodarstw uzyskuje dochody nie większe od dochodu minimalnego, co wskazuje na dość szeroki zakres potencjalnego zagrożenia dochodami zbyt niskimi dla „wiązania końca z końcem”.

Tabela 3. Podstawowe charakterystyki różnicy dochodu rzeczywistego i postulowanego jako minimalny w układzie możliwości „wiązania końca z końcem”

\begin{tabular}{|l|c|c|c|c|}
\hline \multicolumn{1}{|c|}{ „Wiązanie końca z końcem” } & Średnia & Kwartyl 1. & Mediana & Kwartyl 3. \\
\hline z wielką trudnością & $-472,14$ & $-1000,00$ & $-400,00$ & 0,00 \\
\hline z trudnością & $-141,04$ & $-610,00$ & 0,00 & 300,00 \\
\hline z pewną trudnością & 212,00 & $-300,00$ & 50,00 & 600,00 \\
\hline raczej łatwo & 1275,84 & 300,00 & 1000,00 & 1800,00 \\
\hline łatwo & 3048,07 & 975,00 & 1900,00 & 3500,00 \\
\hline ogółem & 428,30 & $-500,00$ & 0,00 & 900,00 \\
\hline
\end{tabular}

Źródło: obliczenia własne na podstawie danych z badania „Diagnoza społeczna” 2013.

W tabeli nr 4 pokazano sposób gospodarowania dochodem ze względu na sposób „wiązania końca z końcem”.

W gospodarstwach o trudnej sytuacji dochodowej ok. 11 proc. spośród nich określa gospodarowanie dochodem, stwierdzając, że starcza na wszystko (suma trzech pierwszych kategorii w tabeli 4), natomiast w gospodarstwach o najlepszej sytuacji takich przypadków jest ponad 96 proc. W grupie gospodarstw o niskich dochodach ok. 10 proc. jest takich, w których dochodów tych nie starcza nawet 


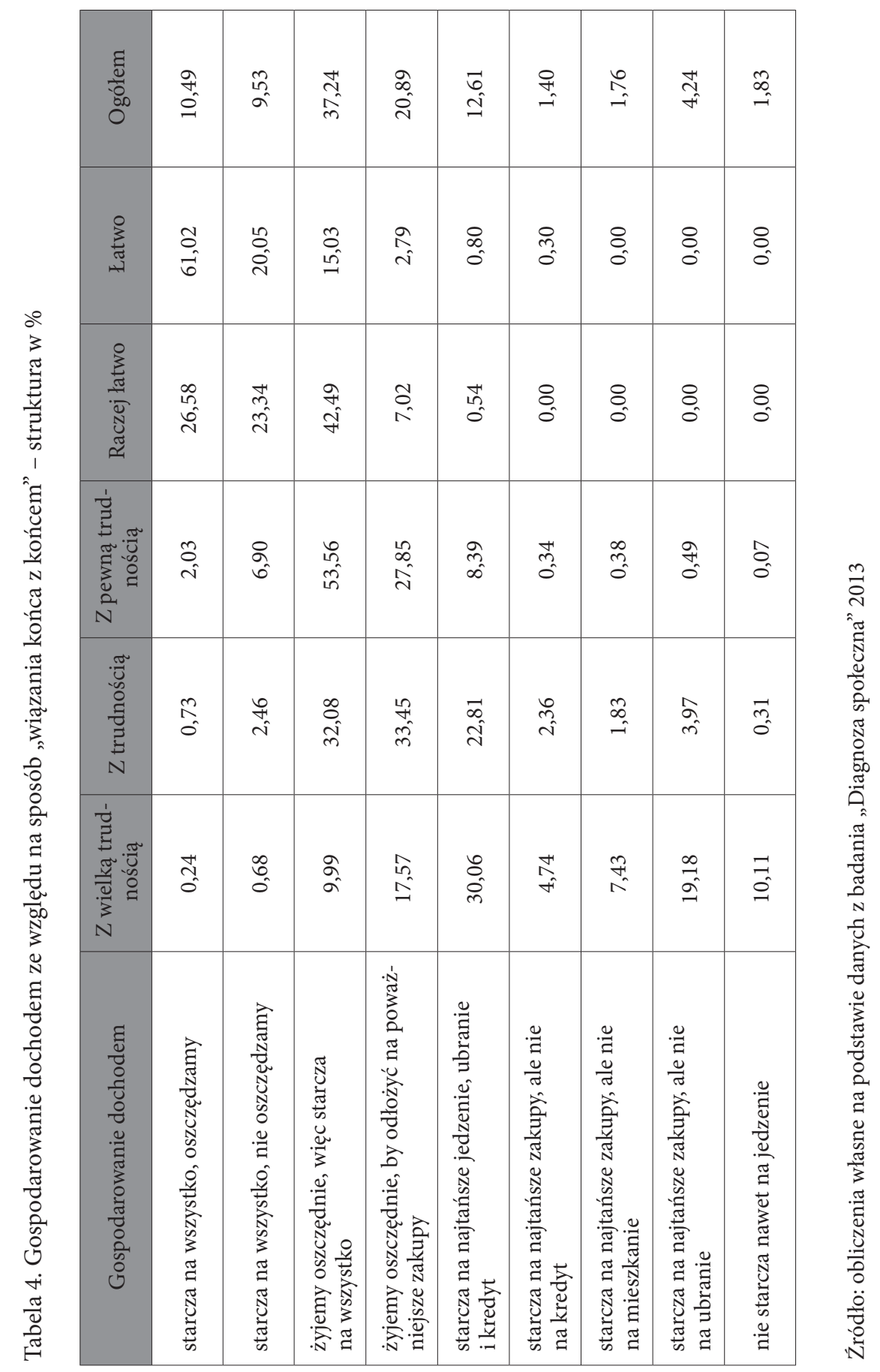


na jedzenie, i blisko 20 proc. takich, w których dochód wystarcza na najtańsze jedzenie, ale nie na ubranie. Biorąc pod uwagę, że jedzenie i ubranie, jak również zamieszkanie wyrażają potrzeby podstawowe, to w tej grupie gospodarstw ponad 35 proc. $z$ nich nie może zrealizować bieżących i podstawowych potrzeb. Pamiętając, że tych najbiedniejszych gospodarstw jest 17 proc., proste przemnożenie powyższych udziałów daje ok. 6 proc. ogólnej liczby gospodarstw skrajnie ubogich, co zgadza się mniej więcej z poziomem skrajnego ubóstwa zaprezentowanego na rys. $1^{12}$. Warto zwrócić uwagę na gospodarstwa domowe wskazujące na pewne trudności w zakresie zaspokajania potrzeb poprzez bieżący dochód. Ponad 80 proc. $z$ nich przyznaje, że żyje oszczędnie, co znajduje potwierdzenie w stwierdzeniu o wspomnianych pewnych trudnościach w zakresie „wiązania końca z końcem”. Owa zgodność potwierdza stabilność oceny swojej sytuacji ekonomicznej wśród badanych gospodarstw domowych.

W wykorzystywanym zbiorze danych znaleźć można zmienną zawierającą informacje na temat odpowiedzi na pytanie, czy stałe dochody pozwalają na zaspokojenie bieżących potrzeb gospodarstwa domowego. Wśród wszystkich gospodarstw domowych blisko 25 proc. było takich, które dało odpowiedź przeczącą, natomiast wśród gospodarstw o niskich dochodach negatywnych odpowiedzi było nieco ponad 75 proc. Powstaje więc pytanie o źródła zaspokojenia tych potrzeb lub sposoby rozwiązania problemu niewystarczających środków finansowych. W tabeli $5 \mathrm{w}$ podobnym układzie jak wyżej pokazano sposoby radzenia sobie z zaspokojeniem bieżących potrzeb gospodarstwa w warunkach niewystarczającego dochodu. Nie uwzględniono tutaj tych gospodarstw domowych, które łatwo „wiążą koniec z końcem”, z powodu ich nikłego udziału wśród gospodarstw domowych o deklarowanej niewystarczalności dochodu.

Gospodarstwa domowe w sytuacji zbyt niskiego dochodu dla zaspokojenia bieżących potrzeb najczęściej ograniczają poziom zaspokojenia tych potrzeb, co jest szczególnie widoczne w przypadku gospodarstw najbiedniejszych. W drugiej kolejności gospodarstwa te korzystają z pomocy krewnych, a następnie zaciągają kredyty lub pożyczki oraz korzystają z pomocy opieki społecznej. Pomoc opieki społecznej jest źródłem zaspokojenia bieżących potrzeb gospodarstwa domowego najbardziej specyficznym dla gospodarstw najuboższych, co z drugiej strony jest uzasadnione celem i zadaniami pomocy społecznej. Warto zwrócić uwagę, że niezbyt częstym rozwiązaniem problemów finansowych gospodarstw jest podjęcie dodatkowej pracy, co może wynikać z niewielkich szans członków tych gospodarstw na znalezienie pracy w ogóle lub pracy odpowiadającej ich

12 Warto zauważyć, że dane zaprezentowane na rysunku 1 odnoszą się do udziału osób. Można więc przypuszczać, że otrzymany wynik 6 proc. dla gospodarstw domowych przełoży się na nieco większy udział osób doświadczających skrajnego ubóstwa. 
aspiracjom albo z powodu niechęci do podejmowania wysiłku wynikającego z pracy przy innych możliwościach zaspokojenia bieżących potrzeb gospodarstw domowych. Z pewnością jest to ciekawe zagadnienie badawcze - wskazanie na przyczyny niepodejmowania pracy dodatkowej przez członków biednych gospodarstw domowych. Taka wiedza pozwoliłaby na bardziej skuteczne działania polityki społecznej i w ramach niej pracy socjalnej.

Tabela 5. Źródła zaspokojenia bieżących potrzeb w gospodarstwach z niewystarczającym dochodem ze względu na sposób „wiązania końca z końcem”

\begin{tabular}{|l|c|c|c|c|c|}
\hline $\begin{array}{c}\text { Aby zaspokoić } \\
\text { bieżące potrzeby gospo- } \\
\text { darstwa domowego: }\end{array}$ & $\begin{array}{c}\text { Z wielká } \\
\text { trudnością }\end{array}$ & $\begin{array}{c}\text { Z trud- } \\
\text { nością }\end{array}$ & $\begin{array}{c}\text { Z pewną } \\
\text { trudnością }\end{array}$ & $\begin{array}{c}\text { Raczej } \\
\text { łatwo }\end{array}$ & Ogółem \\
\hline $\begin{array}{l}\text { wykorzystuje } \\
\text { oszczędności }\end{array}$ & 6,12 & 14,51 & 24,88 & 41,74 & 12,59 \\
\hline wyzbywa się majątku & 7,72 & 5,05 & 1,86 & 3,45 & 5,95 \\
\hline $\begin{array}{l}\text { ogranicza bieżące po- } \\
\text { trzeby }\end{array}$ & 90,56 & 89,12 & 86,50 & 54,00 & 88,68 \\
\hline $\begin{array}{l}\text { zaciąga pożyczki, } \\
\text { kredyty }\end{array}$ & 31,94 & 28,69 & 25,96 & 10,81 & 29,49 \\
\hline $\begin{array}{l}\text { korzysta z pomocy } \\
\text { krewnych }\end{array}$ & 49,06 & 35,33 & 23,97 & 22,28 & 40,08 \\
\hline $\begin{array}{l}\text { korzysta z pomocy Ko- } \\
\text { ścioła }\end{array}$ & 9,41 & 3,30 & 1,84 & 1,11 & 6,14 \\
\hline $\begin{array}{l}\text { korzysta z pomocy opie- } \\
\text { ki społecznej }\end{array}$ & 30,19 & 10,25 & 6,18 & 2,05 & 19,72 \\
\hline $\begin{array}{l}\text { podejmuje dodatkową } \\
\text { pracę }\end{array}$ & 17,30 & 19,35 & 17,27 & 7,85 & 17,75 \\
\hline $\begin{array}{l}\text { podejmuje inne } \\
\text { działania }\end{array}$ & 22,99 & 16,91 & 13,66 & 14,18 & 19,47 \\
\hline niczego nie robi & 8,00 & 5,31 & 8,97 & 10,11 & 7,39 \\
\hline ogółem & 51,29 & 29,46 & 17,10 & 1,77 & $\mathrm{x}$ \\
\hline
\end{tabular}

Źródło: obliczenia własne na podstawie danych z badania „Diagnoza społeczna” 2013

W przypadku prawie 11 proc. ogółu gospodarstw uzyskano informację o korzystaniu z zewnętrznej pomocy odnośnie do zaspokajania potrzeb, co zostało pokazane w tabeli 6 . 
Tabela 6. Pomoc z zewnątrz dla gospodarstwa domowego i jej forma w układzie możliwości „wiązania końca z końcem”

\begin{tabular}{|l|c|c|c|c|c|c|c|}
\hline $\begin{array}{c}\text { Pomoc } \\
\text { Z zewnątrz }\end{array}$ & $\begin{array}{c}\text { Z wielką } \\
\text { trudnością }\end{array}$ & $\begin{array}{c}\text { Z trud- } \\
\text { nością }\end{array}$ & $\begin{array}{c}\text { Z pewną } \\
\text { trudnością }\end{array}$ & $\begin{array}{c}\text { Raczej } \\
\text { fatwo }\end{array}$ & Łatwo & Ogółem \\
\hline $\begin{array}{l}\text { Czy jest pomoc } \\
\text { z zewnątrz }\end{array}$ & 32,56 & 12,80 & 5,95 & 3,11 & 2,04 & 10,93 \\
\hline finansowej & 81,93 & 68,10 & 57,44 & 48,84 & 28,64 & 71,38 \\
\hline rzeczowej & 51,04 & 43,10 & 35,21 & 31,16 & 42,80 & 44,88 \\
\hline w formie usług & 19,51 & 24,24 & 33,46 & 43,79 & 79,11 & 25,73 \\
\hline
\end{tabular}

Źródło: obliczenia własne na podstawie danych z badania „Diagnoza społeczna” 2013

Wśród gospodarstw, które z wielką trudnością „wiązały koniec z końcem”, takich gospodarstw było blisko 33 proc. Pomoc ta mogła być udzielana w formie finansowej, rzeczowej lub w formie usług. Gospodarstwa najbiedniejsze najczęściej pozyskiwały pomoc w postaci finansowej, później rzeczowej i najrzadziej w formie usług. Odwrotnie jest wśród gospodarstw lepiej sytuowanych (ale jednocześnie korzystających z pomocy z zewnątrz). Gospodarstwa ubogie korzystają w znacznej mierze z pomocy społecznej, której instrumentami są różnego rodzaju zasiłki, natomiast w przypadku gospodarstw o lepszej kondycji ekonomicznej pomoc w formie zasiłków jest niedostępna. Możliwości zaspokojenia w pełni bieżących potrzeb w ich przypadku wiążą się z pozyskaniem pomocy rzeczowej lub w formie usług.

\section{Zakończenie}

Niskie dochody gospodarstw domowych w Polsce nie są marginalnym zjawiskiem, co potwierdzają dane na temat ubóstwa identyfikowanego za pomocą absolutnej granicy ubóstwa, jaką jest np. kwota minimum egzystencji. Z drugiej strony można mieć wątpliwości co do wiarygodności danych statystycznych o dochodach gospodarstw domowych uznanych za biedne, zwłaszcza w kontekście poziomu ich wydatków przeciętnie przekraczających w znacznej mierze poziom dochodów. Trudno bowiem przyjąć za racjonalne wytłumaczenie tej sytuacji faktem, że gospodarstwa ubogie kompensują brak dochodów względem wydatków oszczędnościami. Można więc z dużą dozą prawdopodobieństwa 
przypuszczać, że rzeczywiste dochody gospodarstw ubogich są wyższe niż te raportowane. Podstawowym powodem ukrywania dochodów może być ich uzyskiwanie w tzw. szarej strefie, czyli ogólnie mówiąc poza systemem podatkowym, a więc nielegalnie. Podkreślić jednak należy, że takie pozyskiwanie dochodów niekoniecznie musi być wynikiem chęci oszukiwania przez osoby pozyskujące dochody nielegalnie ${ }^{13}$. Często bowiem słyszy się w mediach ${ }^{14}$ o problemie zatrudnienia $\mathrm{z}$ umowami o najniższych płacach i jednoczesną zapłatą części wynagrodzenia poza zapisami umowy lub w ogóle pracy bez umowy, co nierzadko wynika z przymusu pracodawcy kierującego się chęcią obniżenia kosztów działalności gospodarczej. W przypadku biednych gospodarstw domowych może wystąpić również sytuacja, że dodatkowe dochody z niskopłatnej pracy spowodują utratę takiego czy innego zasiłku. Może się więc okazać, że w sytuacji utraty prawa do zasiłku dochody z tej pracy nie powodują znacznej poprawy sytuacji ekonomicznej (dochodowej) gospodarstwa. Postępując więc racjonalnie (od strony ekonomicznej), opłaca się takiej rodzinie ukryć dochody z pracy, aby nie tracić dochodów z zasiłków, i w ten sposób znacząco poprawić swoją sytuację ekonomiczną, albo w ogóle nie podejmować żadnej pracy. Oczywiście ocena moralna zwłaszcza tego pierwszego postępowania jest negatywna, jednak z drugiej strony czy państwo lub społeczeństwo nie przymusza biednych rodzin do takiego kroku? Wracając do rozważań ze wstępu niniejszej pracy, można by zapytać, dlaczego przez tyle lat transformacji systemowej nie udało się systemowo rozwiązać „śmieciowego" zatrudniania na rynku pracy, dlaczego nie ma skutecznej polityki prorodzinnej znowu w ujęciu systemowym, dlaczego ciągle tak mało zarabiamy w odniesieniu do innych państw, nawet nam podobnych (np. Hiszpanii), dlaczego państwo opodatkowuje najbiedniejszych, utrzymując tak niską kwotę wolną od podatku, a tak w ogóle czy w Polsce jest spójny system polityki społecznej rozumianej jako celowe działanie na rzecz rozwoju społecznego. W mojej opinii potrzeba kompleksowych zmian, które wymagają głębokiej refleksji nad obecną sytuacją, celem i działaniami pozwalającymi go osiągnąć.

13 Nie chodzi tutaj o dochody $\mathrm{z}$ nielegalnych źródeł (dochody z przestępstwa), ale o dochody z legalnej działalności społeczno-gospodarczej niezgłaszane do opodatkowania.

14 Nie przytaczam tutaj żadnych danych statystycznych, ponieważ są one niedostępne. Szacuje się natomiast wielkość szarej strefy w gospodarce, która według Instytutu Badań nad Gospodarką Rynkową w 2014 roku wyniosła od 12,8 proc. PKB (według metodologii GUS-u) lub 19,5 proc. PKB (według metodologii IBnGR). Wartościowo są to wielkości wynoszące odpowiednio ok. 220 mld zł i 364 mld zł (K. Łapiński, M. Peterlik, B. Wyżnikiewicz, Szara strefa $w$ polskiej gospodarce, Warszawa 2014, s. 22-23. 


\section{Bibliografia}

Diagnoza społeczna 2013. Warunki i jakość życia Polaków. Raport, pod red. J. Czapińskiego, T. Panka, www.diagnoza.com (dostęp: 15.11.2015).

GUS, Budżety gospodarstw domowych w 2014 r. Informacje i opracowania statystyczne, Warszawa 2015.

GUS, Metodologia badania budżetów gospodarstw domowych, Warszawa 2011.

GUS, Ubóstwo ekonomiczne w Polsce w 2014 r., Opracowanie sygnalne, http://stat.gov.pl/ obszary-tematyczne/warunki-zycia/ubostwo-opieka-spoleczna/ubostwo-ekonomiczne-w-polsce-w-2014-r-,14,2.html (dostęp: 15.11.2015).

Jan Paweł II, Encyklika Centensimus annus.

Jan Paweł II, Encyklika Solicitudo rei socialis.

Kurowski P., Koszyk minimum socjalnego i minimum egzystencji - dotychczasowe podejście, Warszawa 2002.

Łapiński K., Peterlik M., Wyżnikiewicz B., Szara strefa w polskiej gospodarce, Warszawa 2014.

Panek T., Ubóstwo, wykluczenie społeczne i nierówności. Teoria i praktyka pomiaru, Warszawa 2011.

Topińska I., Kierunki zmian w statystyce ubóstwa, w: Pomiar ubóstwa. Zmiany koncepcji i ich znaczenie, pod red. I. Topińskiej, Warszawa 2008. 
4. Uniwersytet Papieski 